\title{
Pengaruh Idola Musik K-Pop (Korean - Pop) Terhadap Perubahan Karakter Remaja di SMAN 5 Karawang
}

\author{
Widdy Assa Melian \\ Prodi Pendidikan Pancasila dan Kewarganegaraan, Fakultas Keguruan dan Ilmu Pendidikan, Universitas Buana \\ Perjuangan Karawang \\ pk16widdyassamelian@mhs.ubpkarawang.ac.id
}

Tridays Repelita

Prodi Pendidikan Pancasila dan Kewarganegaraan, Fakultas Keguruan dan Ilmu Pendidikan, Universitas Buana Perjuangan Karawang tridays.repelita@ubpkarawang.com

Lusiana Rahmatiani

Prodi Pendidikan Pancasila dan Kewarganegaraan, Fakultas Keguruan dan Ilmu Pendidikan, Universitas Buana Perjuangan Karawang lusiana.rahmatiani@ubpkarawang.ac.id

\begin{abstract}
ABSTRAK
Penelitian ini dilatar belakangi oleh keinginan penulis unuk mengetahui perubahan karakter yang dialami remaja yang menggemari idola musik K-Pop (Korean Pop), Penelitian ini termasuk kedalam jenis penelitian kuantitatif, peneltian kuantitafif yang diistilahkan dengan penelitian ilmiah yang menekan kepada angka - angka. Tahapan dalam penelitian ini yaitu uji instrumen, pengumpulan data, menganalisa data, serta menginterpretasikan data. Populasi dalam penelitian ini adalah seluruh siswa SMAN 5 Karawang yang berjumlah 1. 263. Siswa sample dalam penelitan ini sebanyak kelas, dalam pengambilan sampel peneliti menggunakan teknik Simple Random Sampling yaitu pengambilan sample secara acak tanpa memperhatikan strata yang ada dalam popluasi. Dari hasil penelitian diperoleh hasil ( $\left.\mathrm{t}_{\text {hitung }} 3,021>\mathrm{t}_{\text {tabel }} 1,275\right)$ hasil tersebut menunjukkan bahwa hipotesis pengaruh Idola K-Pop terhdap perubahan karakter remaja $\left(\mathrm{H}_{1}\right)$ dapat diterima. Rekomendasi dari penelitian ini, Pertama, pihak sekolah disarankan lebih mendalami mata pelajaran Pendidikan Pancasila dan Kewarganegaran untuk menumbuhkan rasa nasionalisme kepada siswa ditenga gempuran budaya asing yang semakin menyebar di Indonesia,. Kedua, disarankan kepada remaja untuk lebih bisa mengontrol diri dan memahami tidak semua budaya asing dapat diimplementasikan kedalam kehidupan sehari - hari.
\end{abstract}

Kata Kunci : Idola K-Pop, Remaja, Karakter,

ABSTRACT

This research is motivated by the author's desire to know the character changes experience by adolescents who love K-Pop (Korean Pop) music idols.This research is included in the type of quatitative research, quantitatif research which is termed scientific research that presses in this research are instrumnt testing, data collection, data analysis, and data interpretaion.The population is all student of SMAN 5 Karawang, totaling 1.263.The sample student in this study were as many as class, in taking the sample the researcher used the simple random sampling without paying attention to the exsiting strata in the population. From the research result obtained (tcount $3.021>$ ttable 1.275) these result indicate that the hypothesis of the influence of K-Pop idols on changes in adlescent character $\left(\mathrm{H}_{1}\right)$ can be accepted. The recomendations of this study are, frist the school is advised to further explore the subject of Pancasila and Civic Education to build of natinalism in students amidst the attacks of foreign cultures that are increasingly spreading in Indonesia. Second, it is recommended that adolescents be more able to control themselves and understand thar not all foreign cultures can be implemented into daily life. Keyword : K-Pop Idols, Teenagers, Personality

\section{PENDAhUluan}

Dewasa ini budaya Korea telah menyebar ke berbagai belahan dunia tidak terkecuali Indonesia dengan berkembangnya teknologi, K-Pop (Korean Pop) dengan cepat masuk ke ranah industri Indonesia. Hal ini dapat dilihat dari perkembangan budaya K-Pop yang sudah menyebar luas di Indonesia. Maksud dari budaya Korea disini yaitu semua 
unsur yang mencirikan Korea seperti, Film, drakor (drama korea), makanan, dan juga hanbok (pakaian adat Korea).

Fenomena Korean Wafe (demam Korea) menimbulkan pula sikap fanatisme terhadap budaya K-Pop (pertama), K-Pop yang menimbulkan penggemar fanatik secara tidak langsung juga membentuk sebuah gaya hidup yang baru bagi penggemar itu sendiri (kedua). Dalam fenomena ini, para penggemar K-Pop mengonsumsi sebuah produk budaya (tiga). Refleksi dari interpretasi penggemar tersebut terhadap materi yang dimanfaatkan akan menciptakan gaya hidup (empat). Gaya hidup yang terbentuk akan memberikan identitas tertentu bagi diri mereka (Santika, 2019). Dengan kata lain, pemilihan konsumsi produk budaya akan termanifestasi ke dalam gaya hidup.

Korean Wafe ( demam Korea ) awal mula melejit pada 1997 melalui drama korea yang berjudul "What is Love All About" ditayangkan di stasiun televisi china, semenjak saat itu budaya Korea mulai merebak dan mendapaat dari pemerintah Korea Selatan, karena menambah pendapatan penghasilan Negara melalui industry hiburan. Kesuksesan Korea Selatan dalam industri hiburan juga turut melibatkan nilai - nilai budaya Korea yang juga ikut dikenal dunia.

K-Pop memiliki ciri khas musik yang dapat memberikan kesenangan tersendiri bagi para penikmatnya, sehingga semakin digemari dan dikonsumsi oleh banyak orang setiap harinya. Konsumsi dari K-Pop pada akhirnya akan memunculkan kelompok penggemar yang merupakan bagian paling tampak dari khalayak teks dan praktik budaya (Storey, 2006)

Indonesia pun tak lepas dari gempuran virus K-Pop ini. Budaya K-Pop awalnya hanya mengacu pada musik pop dari Korea Selatan, namun seiring berkembangnya zaman budaya K-Pop semakin meluas, bukan hanya musik tapi juga film, drama, dan variety show.

Akulturasi (percampuran budaya lama dan baru tanpa meninggalkan budya lama) budaya Indonesia dan budaya Korea pertama kali masuk ke Indonesia pada acara KoreaJapan World Cup 2002 yang berakhir dengan masuknya Korea sebagai kekuatan empat besar dunia dalam hal persepakbolaan. Hal tersebut semakin membuat nama Korea mendunia dan beberapa televisi swasta di tanah air bersaing untuk menayangkan film-film maupun dramadrama Korea” (Amrullah \& Lestari, 2016:)

Layaknya budaya barat atau budaya luar yang lainnya yang berkembang di Indonesia, setiap budaya yang masuk ke Indonesia memiliki dua sisi yang berbeda yaitu dan buruk, begitupun budaya Korea atau K-Pop itu sendiri. Menjadi penggemar K- Pop pun memiliki sisi baik dan buruk.

Masa remaja merupakan masa peralihan dari masa kanak-kanak menuju ke masa dewasa, sifat-sifat remaja sebagian sudah tidak menunjukkan sifat-sifat masa kanak-kanaknya, tetapi juga belum menunjukkan sifat-sifat sebagai orang dewasa (Santika, 2017). Pada masa remaja pergaulan dan interaksi sosial dengan teman sebaya bertambah luas dan kompleks dibandingkan dengan masa-masa sebelumnya termasuk pergaulan dengan lawan jenis. Remaja mencari bantuan emosional 
dalam kelompoknya. Salah satu sikap yang sering ditampilkan para remaja dalam kelompok adalah konformitas, yaitu selalu ingin sama dengan anggota kelompok yang lain (Izzaty, 2013:122). Remaja memiliki emosi yang tidak stabil, karena masa remaja meruapakan masa peralihan dari kanak - kanak menuju dewasa. Sifat remaja mudah sekali berubah tergantung dilingkungan mana ia berada. Karena masa peralihan ini lah remaja di anggap belum bisa menentukan pilihan hidupnya karena emosi yang dimiliki tidak stabil. Berdasarkan Fenomena di atas, peneliti tertarik untuk melakukan penelitian mengenai perubahan karakter

\section{METODE}

Penelitian ini termasuk kedalam jenis penelitian kuantitatif, peneltian kuantitafif yaitu penelitian ilmiah yang menekan kepada angka angka dan analisis menggunakan statisik.

Tahapan dalam penelitian ini yaitu uji instrumen, pengumpulan data, menganalisa data, serta menginterpretasikan data. Proses pengumpulan data utama dilakukan dengan kuesioner yaitu membuat serangkaian pertanyaan untuk memperoleh data. Teknik sampling dalam penelitian ini menggunakan Simple Random Sampling yaitu penggambilan anggota sampel dari populasi dilakukan secara acak tanpa memperhatikan srata yang didalam populasi itu.

\section{HASIL DAN PEMABAHSAN}

Penelitian ini termasuk penelitian kausal yang dimaksud dari penelitian kausal kausal adalah penelitian yang bersifat sebab dan akibat, jadi disini ada variabel independen (variabel yang mempengaruhi)dan dependen (variabel yang dipengaruhi). Adapun teknik sampling yang digunakan adalah dalam penelitian ini menggunakan Simple Random Sampling yaitu penggambilan anggota sampel dari populasi dilakukan secara acak tanpa memperhatikan strata didalam populasi itu. Berdasarkan hasil penelitian yang dilakukan, dapat diketahui bahwa besaran nilai koefisien korelasi adalah 0,39 yang menandakan adanya hubungan (korelasi) yang menyebabkan perubahan karakter yang terhadap remaja termasuk kategori korelasi yang lemah.

Pada Uji Signifikansi (Uji T) Variabel bebas terhadap variabel terikat nilai $\mathrm{t}_{\text {hitung }} 3,021$ lebih besar dari $t_{\text {tabel }} 1,275$ hasil tersebut menunjukkan bahwa hipotesis pengaruh Idola K-Pop terhdap perubahan karakter remaja $\left(\mathrm{H}_{1}\right)$ dapat diterima. Berikut hasil uji $\mathrm{T}$ pada penelitian ini : 


\section{Coefficients $^{\mathrm{a}}$}

\begin{tabular}{|c|c|c|c|c|c|}
\hline \multirow[b]{2}{*}{ Model } & \multicolumn{2}{|c|}{ Unstandardized Coefficients } & $\begin{array}{l}\text { Standardized } \\
\text { Coefficients }\end{array}$ & \multirow[b]{2}{*}{$\mathrm{T}$} & \multirow[b]{2}{*}{ Sig. } \\
\hline & B & Std. Error & Beta & & \\
\hline 1 (Constant) & .044 & .393 & & .113 & .911 \\
\hline IDOLA & .207 & .069 & .396 & 3.021 & .004 \\
\hline
\end{tabular}

a. Dependent Variable: REMAJA

Tingkat kolerasi dan hubungan yang cukup serta sesuai dengan indikator kontribusi besar Idola dalam kehidupan penggemar. Sobur (Sobur, dkk., 2018 : 414 - 422) menemukan tiga transformasi konsep K-Popers yaitu : (1) Transformasi dari maskulin menjadi feminim (2) Transformasi dari inrovert menjadi ekstrovert (3) Transformasi dari konsep fifkiran yang tertutup. Bagi penggemar K-Pop idola merupakan sosok yang menjadi pedoman dalam berperilaku karena mayoritas penggemar K-Pop adalah remaja seperti yang kita ketahui diusia remaja identitas mereka belum terbentuk sepenunya, jati diri mereka belum komplet dan masih bisa terbentuk karena faktor - faktor lainnya.

Untuk arah korelasi antara pengaruh idola musik k-pop terhdap perubahan karakter remaja memiliki hubungan kausal yang positif. Positif disini mengandung arti bahwa hubungan antara variabel independen dan dependen terikat bersifat searah. Dari hasil uji model keseluruhan dapat diketahui juga Fhitung > Ftabel $(29,>4,03)$. Dengan nilai signifikansi $0,04<0,05$ pada table berikut :

ANOVA ${ }^{\mathrm{a}}$

\begin{tabular}{|rr|r|r|r|r|r|}
\hline Model & Sum of Squares & Df & Mean Square & F & Sig. \\
\hline $1 \quad$ Regression & 10.998 & 1 & 10.998 & 9.128 & $.004^{\text {b }}$ \\
& Residual & 59.041 & 49 & 1.205 & & \\
& & & & & & \\
& Total & 50.039 & & & & \\
\hline
\end{tabular}

a. Dependent Variable: REMAJA

b. Predictors: (Constant), IDOLA

Saunders, (1977:126) menjelaskan bahwa karakter adalah sifat nyata dan berbeda yang ditunjukkan oleh individu, sifat-sifat kejiwaan, akhlak atau budi pekerti yang membedakan seseorang dari yang lain, tabiat, watak.
Berkarakter berarti memiliki watak, memiliki kepribadian (Santika, 2018).

Apabila siswa terlalu fanatik terhadap sang idola ataupun terlalu mmenyukai budaya Korea tentu akan mempengaruhi kegiatannya 
sehari -hari, gaya hidup hidup yang ditimbulkan bisa berupa gaya hidup yang positif maupun negatif, berikut ini adalah gaya contoh dampak positif bagi remaja penggemar $\mathrm{K}$-Pop yang sudah disimpulkan oleh peneliti berdasarkan hasil penelitian yang menjadi Dampak Positif yaitu (1) Remaja dapat mengetahui budaya asing dan mempelajari bahasa asing (2) Remaja dapat mengerti bahasa Korea \& Bahasa Inggris (3) Remaja dapat menirukan gaya hidup masyarakat Korea yang terkenal disiplin Menambah wawasan bermedia sosial sehingga mudah mendapat teman baik dari dalam dan luar negeri (4) Dapat mengembangkan hobi menjadi karir, penggemar yang menyukai K-Pop biasanya mempelajari bahasa korea bakat ini bisa dikembangkan menjadi terhadap jenjang karir seperti menjadi penerjemah. Sedangkan hasil dari dampak negatif yang sudah disimpulkan oleh peneliti yaitu : (1) Remaja lebih menyukai budaya Korea daripada budaya sendiri, lebih mengkiti tren Korea seperti Korean fashion, korean food dan tren dari korea lainnya bahkan remaja menggunakan bahasa Korea kedalam kehidupan sehari - sehari (2) Remaja meniru budaya korea yang tidak pantas jika diterapkan di Indonesi (3) menutup ruang lingkup pertemanan, berteman dengan sesama penggemar musi K-Pop.

\section{PENUTUP}

\section{Simpulan}

Hasil penelitian ini memberikan gambaran perubahan yang dialami remaja yang menggemari msuik K-Pop (Korean Pop), cinta dan Fanatik yang berlebihan penggemar mengidolakan Idol K-Pop menyebebkan mereka mengalami transformasi kepribadian atau perubahan karakter. Selain karena rasa cinta yang berlebihan transformasi yang dialami remaja dikarenakan mereka sedang berada diusia yang selau ingin mencarai jati diri atau jati diri mereka belum terbentuk sepenuhnya masih banyak fakor yang bisa mempengaruhi karakternya. Transformasi yang dialami remaja ini tidak selalu berdampak negatif seperti stigma yang sudah diberikan masyarakat terhadap mereka tetapi juga banyak dampak positif yang dialami remaja penggemar K-Pop yang mungkin tidak dialami remaja seusia mereka lainnya. Remaja diharapkan dapat mengontrol atau mengendalikan emosinya dan perlu memahami dampak positif maupun negatif dalam mengkunsumsi budaya asing karena tidak semua budaya asing bisa di implementasikan kedalam kehiduan sehari hari.

\section{DAFTAR PUSTAKA}

Elsa, Rizky (2018) "Gambaran Identitas Diri Remaja Akhir Pengggemar Drama Korea" Skripsi Universitas Muhammaia Surakarta

Etika Sari Yulia. (2018). "Kontrol Diri Remaja Penggemar K-Pop. Skripsi: Universtias Negeri Yogyakarta“.

Hindun, Sufi (2018), “Tingkat Fanatisme Penggemar K-Pop dan Kemampuan mengelola Emosi" Jurnal Riset Mahasiswa dan Bimbingan Konseling, 7 (2),

Khairil, Muhammad (2019) "Efek Ketergantungan Remaja K-Popers terhadap Media Sosial di Kota Palu" Jurnal ASPIKOM, Volume 4 Nomor 1, Juli 2019, hlm 14 -25

Niuraeni, Niken (2017). "Fanatisme fans K-Pop : Candu dan Bumbu Remaja" Retrived from https:kumparan.com/@kumparan- 
pop/fanatisme-fans-k-pop-candu-dan-bumburemaja.

Nur, Yeni (2016). "Perilaku Penemuan Informasi Pada Komunitas K-Pop "Ever Lasting Friend (ELF)" Surabaya.

Maiharoh, Putri (2020).“Kprelasi Anatar Korean Culture Dengan Karakter Siswa Di Madraaliyah Ngeri (Man) Sidoarjo".Skrispi Uin Sunan Ampel Surabaya 1

Rachmad, Asfira "Fanatisme Penggemar Kpop Dalam Bermedia Sosial Di Instagram “ Jurnal Ilmu Komunikasi Vol. 8, No, 2, Desember 2019

Rosalyn, Citra (2018). "Mahasiswa Dan K-Pop (StudI intraksi Simbolik K-Popers di Makassar" Jurnal Ilmu Komunikasi UPN Veteran Jatim. 1 (1)

Santika, I. G. N. (2018). Strategi Meningkatkan Kualitas SDM Masyarakat Padangsambian Kaja Melalui Pendidikan Karakter Berbasiskan Kepedulian Lingkungan Untuk Membebaskannya Dari Bencana Banjir. Widya Accarya. 9 (2).

Santika, I. G. N. (2017). Kepala Sekolah Dalam Konsep Kepemimpinan Pendidikan: Suatu Kajian Teoritis. Widya Accarya. 7 (1).

Santika, I. G. N., Rindawan, I. K., \& Sujana, I. G. (2019). Memperkuat Pancasila Melalui Pergub No. 79 Tahun 2018 Dalam Menanggulangi Pengikisan Budaya Di Era Revolusi Industri 4.0. Prosiding Seminar Nasional Inobali 2019, 79, 981-990

Santika, I. G. N. (2021). Pendidikan Kewarganegaraan (Studi Komparatif Konstitusi Dengan UUD 1945). Jawa Tengah: Lakeisha

Sugiono. (2014). "Metode Penelitian Kuantitatif Kualitatif Dan R\&D”. Bandung: PT Alfabe-Ta Bandung. 